\title{
Histopathology, haematology and serum chemistry of growing pigs fed varying levels of wild sunflower (Tithonia diversifolia) leaf meal as protein supplements
}

\author{
Fasuyi A.O., Ibitayo F.J., Alo S.O. \\ Department of Animal Production \& Health Sciences, Faculty of Agricultural Sciences, Ekiti State \\ University, Ado-Ekiti, P.M.B. 5363, Ado-Ekiti, Ekiti State, Nigeria.
}

\begin{abstract}
Tithonia diversifolia (wild sunflower) leaf meal (TDLM) was prepared and fed to 24 Large White growing pigs in 3 varying inclusion levels $(10 \%, 20 \%$ and $30 \%)$ as protein supplements in a completely randomized designed experiment. Haematological and histopathological examinations were carried out. White blood cells (WBC) count of pigs on 30\% TDLM diet had the highest ( $p<0.05)$ WBC value of $18083 \mathrm{~mm}^{3}$. The urea and creatinine values increased across the increasing inclusion of TDLM may be suggestive of nephotoxic

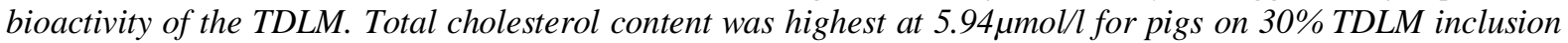
and decreased as the TDLM inclusion declined. There were noticeable degeneration, bleeding and inflammation of the stomach inner linings and external appearance of the large intestine. It can be concluded that safe nutritional regimes existed below and at levels not exceeding 20\% TDLM inclusion in diets of growing pigs when used as protein supplement. Tithonia diversifolia leaf meal (TDLM) could be a suitable health diet to combact some fatty acid metabolic diseases at 10\% inclusion in the diet of pigs. The histopathology revealing severe epithelial erosion and haemorrages could be instructive of the toxicological effects of TDLM at high inclusion levels above $20 \%$.
\end{abstract}

Keywords: Histopathology, haematology, serum chemistry, Tithonia diversifolia

\section{Introduction}

Blood parameters have been shown to be major indices of physiological, pathological and nutritional status of an organism and changes in the constituent compounds of blood when compared to normal values, could be used to interprete the metabolic state of an animal as well as quality of feed [1]. Administration of a chemical compound may bring about significant changes in the structure, function, metabolic transformation and concentration of biomolecules, enzymes and even metabolic pathways. These alterations, which may be rapid or slow may lead to different biochemical mechanisms producing similar pathological, clinical and laboratory findings [2].

Assessment of heamatological parameters can be used to determine the extent of deleterious effect of foreign compound including plant extracts on the blood. Such laboratory investigations have been reported to be highly sensitive, accurate and reliable, and it remains the bedrock of ethical and rational research, disease diagnosis, prevention and treatment [3,4].

Despite the predictive possibility of green forages as livestock (monogastric) feed supplement, the presence of antinutritional factors and their high fibre levels have constantly been the major obstacles in the ample use of these green forages [5].

However, pigs have been fingered as particular monogastric specie with remarkable capacity to consume and digest fibre, and leaves from trees, shrubs and crop plants that are relatively high in fibre [6].

Tithonia diversifolia (wild sunflower) is a green forage plant that can be utilized as feed stuff for animals due to its protein content $[7,8]$. There have been various information that exist on the effects of wild sunflower (Tithonia diversifolia) leaf meal on the growth performances, carcass traits and haematological indices of poultry birds, rabbits, ruminants and pigs $[9,10,11]$.

Therefore, the objective of the present study is to assess the health status of growing pigs fed varying levels of TDLM as protein supplements through the determination of their haematological parameters and histopathological assessment in cases of mortality.

\subsection{Preparation of test ingredients}

\section{Materials And Methods}

The test ingredients Tithonia diversifolia leaf meal (TDLM) was prepared by harvesting daily, the fresh and matured leaves of Tithonia diversifolia plants of different ages before flowering. The whole leaves were chopped manually using kitchen knives and then sun-dried. Sun-drying was done for 4 days, and the chopped leaves were manually turned using a rake so as to guarantee even-drying to $12-13 \%$ moisture content. Fresh and 
dried samples of Tithonia diversifolia leaves were taken to the laboratory for proximate and chemical analyses even before the inclusion of the dried samples into the diets.

\subsection{Experimental animals}

A total of 24 male growing pigs (about $2 \frac{1}{2}$ months old) of commercially available Large White breed with a mean body weight of $13.3 \pm 0.5 \mathrm{~kg}$ were used for this study. The experimental pigs were given adequate medication to prevent piglet anaemia and worms at the first week of their arrival.

\subsection{Feeding trial study}

The feeding trials were carried out at the piggery unit of the Teaching and Research Farm (TRF) of the Ekiti State University, Ado-Ekiti. The 24 male growing pigs were all randomized into separate pens for this prefeeding trial. They were initially served a standard growing diet for pigs compounded with conventional feedstuffs for acclimatization for a period of 10 days. Daily feeding rate was $3.30 \%$ of the pigs' live weight [12].

Water was given to the pigs ad libitum throughout the period of the standardization trial. The daily feed consumption in $\mathrm{g} /$ day was calculated and divided by the average daily weight gain to obtain the feed conversion ratio means for all the pigs on the standard pig diet.

The feeding trial proper was carried out for 102 days with four diets (D1, D2, D3 and D4) formulated to contain about $19.0 \%$ crude protein and a digestible energy value of about $12.55 \mathrm{MJ} \mathrm{kg}^{-1}$. The control diet was a standard growing diet for pigs compounded with conventional feed stuffs e.g. maize, soybeans, palm kernel cake (PKC), oyster shell, bone meal, brewer's dry grain (BDG), wheat offals, fish meal, salt and grower premixes. The other three diets were compounded such that Tithonia diversifolia leaf meal (TDLM) progressively replaced soybeans at $10 \%, 20 \%$ and $30 \%$ inclusion levels in diets 2, 3 and 4, respectively. Daily feeding rate was $3.30 \%$ of the pigs' live weight [12]. Water was given to the pigs ad libitum throughout the period of the experiment. The daily feed consumption in g/day was calculated and was divided by the average daily weight gain, to get the feed conversion ratio means for all the pigs on the four experimental diets.

\subsection{Haematological assessment}

Blood samples collection was done on day 102 of the feeding trial. It was done in the morning after the pigs were starved overnight in order to attain a stable haematological evaluation and also for easy handling. Four pigs were randomly selected from each experimental diet, and blood samples were collected with the aid of 10-guage needle inserted into the anterior vena cava. Two sets of blood samples were taken from each pig to determine the haematological indices and serum metabolites.

Blood samples meant for haematological parameters were emptied into vacutainer tubes containing ethylene diamine tetra-acetic acid (EDTA) as anti-coagulant. The tubes were immediately capped and the contents mixed gently for about 1 minute by repeated inversion. The samples were then taken immediately to the laboratory to determine packed cell volume (PCV), white blood cells (WBC), neutrophils (N), lymphocytes (L), monocytes (M) and eosinophils (E). PCV was determined by the micro-haematocrit method [13]. WBC was estimated using the improved Neubaver haemocytometer method as described by [14]. Neutrophils (N), eosinophils (E), lymphocyte (L) and monocyte (M) were determined [15].

Blood samples meant for serum metabolites were collected in vacutainer tubes without anticoagulants and sent to the laboratory. The tubes were kept in a slanting wooden rack, and the blood samples were allowed to clot overnight. The serum (supernatant) was separated clearly by decanting after the blood samples were spun in a centrifuge at $3000 \mathrm{rpm}$ for 10 minutes. The serum samples were kept in sterile vacutainer tubes and kept deep frozen at $-10^{\circ} \mathrm{C}$ prior to analysis to determine urea [16], total cholesterol [17], aspartate aminotrasferase (AST) [18] and alanine aminotransferase (ALT) [19] activities using spectrophotometric method. Total protein (TP) was determined [20], while albumin was determined using the BCG (bromocresol green) method [20].

\subsection{Histopathology}

Histopathology was conducted for some organs obtained from the only dead pig in the diet containing the highest TDLM inclusion level of 30\%. Typical organ samples of the large and small intestine, liver, kidney and lungs of the dead pig placed on the highest inclusion level of TDLM at 30\% was taken to the laboratory for histopathology and cells examination. Typical treatments of these organs were carried out before they were examined with a light microscope as described [21] as follows:

1.5.1 Fixation was done with some agents, such as formalin, that will coagulate the protein and prevent further changes in the tissues of the organ such as autolysis and bacterial action. 
1.5.2 Embedding of the tissue of this organ was done by immersing in paraffin or nitrocellulose to permit the cutting of very thin sections. Since most embedding media are not water-soluble, the fixed tissue was dehydrated and then infiltrated with xylene, which is miscible with the embedded medium.

1.5.3 Sectioning of the tissue was carried out to obtain very thin slices (between 2 and $20 \mu$ in thickness), so that the sections could be placed on a glass slide using a microtome which consisted of a sharp knife blade and a mechanism for moving the tissue past the blade and then advancing it a definite distance after each cutting.

1.5.4 Staining of the cut sections was done with hematocyline together with eosine ( $\mathrm{H} \& \mathrm{E}$ stain) so that different cells or different parts of cells can be differentiated according to colour. The hematocylin would stain the acid portions of a cell dark blue or purple (called basophilic areas) and the eosin would stain the basic portions of a cell pink to red (called acidophilic areas).

1.5.5 Examination of the stained sections of tissues on the slide by means of a microscope and light transmitted through the section was the last step. Magnified photographs were taken of the examined sections.

1.6 Statistical analysis

The data collected in the completely randomized experimental design (CRD) were subjected to statistical analysis using the Minitab Computer Software package [22]. A significant difference was considered at level of $\mathrm{p}>0.05$

Table 1. Haematological indices of pigs fed varying levels of TDLM- based diets

\begin{tabular}{|c|c|c|c|c|}
\hline \multirow[b]{4}{*}{ Parameters } & \multicolumn{4}{|c|}{ Diets } \\
\hline & l & 2 & 3 & 4 \\
\hline & \multicolumn{4}{|c|}{$\%$ inclusion levels of TDLM } \\
\hline & 0 & 10 & 20 & 30 \\
\hline Packed cell volume (PCV), \% & $30.20 \pm 0.43^{\mathrm{a}}$ & $40.20 \pm 0.39^{b}$ & $40.10 \pm 0.41^{b}$ & $41.06 \pm 0.45^{b}$ \\
\hline White blood cells (WBC), $\mathrm{mm}^{3}$ & $6298 \pm 0.56^{\mathrm{a}}$ & $3931 \pm 0.49^{b}$ & $16105 \pm 0.43^{c}$ & $18093 \pm 0.51^{\mathrm{d}}$ \\
\hline Neutrophils (N), \% & $30.25 \pm 3.21^{\mathrm{a}}$ & $36.10 \pm 2.43^{b}$ & $35.20 \pm 3.43^{b}$ & $35.15 \pm 4.10^{b}$ \\
\hline Lymphocytes (L), \% & $58.10 \pm 1.58^{\mathrm{a}}$ & $50.15 \pm 2.53^{b}$ & $50.10 \pm 3.15^{b}$ & $51.15 \pm 2.97^{c}$ \\
\hline Monocytes (M), \% & $8.10 \pm 3.56^{\mathrm{a}}$ & $10.15 \pm 3.03^{b}$ & $10.05 \pm 4.31^{b}$ & $10.15 \pm 3.34^{b}$ \\
\hline Eosinophils (E), \% & $4.05 \pm 5.46^{\mathrm{a}}$ & $4.10 \pm 3.42^{\mathrm{a}}$ & $5.05 \pm 3.21^{b}$ & $4.05 \pm 2.45^{\mathrm{a}}$ \\
\hline
\end{tabular}

${ }^{\mathrm{a}, \mathrm{b}, \mathrm{c}}$ Mean values within rows with different superscript letters are significantly different $(P<0.05)$

Table 2. Serum metabolites of experimental pigs fed varying levels of TDLM based diets

\begin{tabular}{|c|c|c|c|c|}
\hline \multirow[b]{4}{*}{ Parameters } & \multicolumn{4}{|c|}{ Diets } \\
\hline & 1 & 2 & 3 & 4 \\
\hline & \multicolumn{4}{|c|}{$\%$ inclusion levels of TDLM } \\
\hline & $\mathbf{0}$ & 10 & 20 & 30 \\
\hline Urea, mmol/ & $5.89 \pm 2.25^{\mathrm{a}}$ & $3.72 \pm 2.45^{\mathrm{b}}$ & $6.04 \pm 2.32^{c}$ & $4.19 \pm 2.42^{\mathrm{d}}$ \\
\hline Creatinine, umol/ & $63.69 \pm 3.49^{\mathrm{a}}$ & $136.39 \pm 4.42^{b}$ & $150.06 \pm 5.01^{c}$ & $150.12 \pm 4.21^{\circ}$ \\
\hline Total cholesterol, umoll & $4.42 \pm 3.39^{\mathrm{a}}$ & $4.15 \pm 4.42^{\mathrm{b}}$ & $4.90 \pm 5.32^{c}$ & $5.94 \pm 4.50^{\mathrm{d}}$ \\
\hline Triglyceride, $\mathrm{mmol} /$ & $1.06 \pm 2.37^{\mathrm{a}}$ & $0.74 \pm 3.32^{\mathrm{b}}$ & $0.36 \pm 3.45^{c}$ & $0.37 \pm 3.67^{c}$ \\
\hline Aspartate aminotransferase, $\mathrm{mmol} /$ & $67.10 \pm 3.65^{\mathrm{a}}$ & $125.10 \pm 3.23^{b}$ & $52.05 \pm 2.97^{\mathrm{c}}$ & $47.15 \pm 2.21^{\mathrm{d}}$ \\
\hline Alanine aminotransferase, $\mathrm{mmol} / \mathrm{l}$ & $34.05 \pm 4.52^{\mathrm{a}}$ & $29.20 \pm 3.65^{b}$ & $39.05 \pm 2.96^{c}$ & $25.15 \pm 2.78^{\mathrm{d}}$ \\
\hline Y-glutamyl transferase, $\mathrm{mmol} /$ & $42.44 \pm 2.98^{\mathrm{a}}$ & $10.58 \pm 3.94^{b}$ & $31.36 \pm 4.45^{\mathrm{c}}$ & $10.65 \pm 3.98^{b}$ \\
\hline Alkaline phosphatase, $\mathrm{mmol} / \mathrm{l}$ & $107.70 \pm 4.21^{\mathrm{a}}$ & $88.43 \pm 3.87^{b}$ & $73.10 \pm 4.01^{\mathrm{c}}$ & $84.65 \pm 3.96^{\mathrm{d}}$ \\
\hline Total protein, ng/l & $0.46 \pm 2.34^{\mathrm{a}}$ & $0.47 \pm 2.78^{\mathrm{a}}$ & $0.45 \pm 2.54^{\mathrm{a}}$ & $0.4 \pm 3.21^{\mathrm{a}}$ \\
\hline Albumin, ng/1 & $26.28 \pm 1.43^{\mathrm{a}}$ & $28.18 \pm 1.75^{b}$ & $24.42 \pm 1.67^{c}$ & $29.10 \pm 2.11^{\mathrm{d}}$ \\
\hline
\end{tabular}

${ }^{\mathrm{a}, \mathrm{b}, \mathrm{c}}$ Mean values within rows with different superscript letters are significantly different $(P<0.05)$ 


\section{Results And Discussion \\ 3.1 Haematological and histopathological implications of TDLM as protein supplements in pig feed}

Haematological indices are presented in Table 1. Packed cell volume (PCV), neutrophils and monocytes were not significantly ( $p>0.05)$ affected as the levels of TDLM increased in dietary treatments. The white blood cells (WBC) count values from blood samples of pigs were significantly affected $(\mathrm{p}<0.05)$ by the varying levels of TDLM inclusion at $0 \%, 10 \%, 20 \%$ and $30 \%$ in diets 1, 2, 3 and 4 respectively. Pigs on diet 4 had the highest $(\mathrm{p}<0.05)$ value of $18093 \mathrm{~mm}^{3}$, followed by those on diets 3 and 1 at $16105 \mathrm{~mm}^{3}$ and $6298 \mathrm{~mm}^{3}$, respectively. WBC value for pigs on diet 2 had the lowest $(p<0.05)$ value of $3932 \mathrm{~mm}^{3}$.

Apart from diet 1 whose pigs had the significantly lowest $(\mathrm{p}<0.05)$ average value of neutrophils $(\mathrm{N})$ at $30.25 \%$, diets 2,3 and 4 had similar values ( $p>0.05$ ) of $36.10 \%, 35.20 \%$ and $35.15 \%$, respectively.

A significantly highest $(\mathrm{p}<0.05)$ lymphocytes $(\mathrm{L})$ value was recorded for pigs on the control diet 1 at $58.10 \%$. Pigs on diets 2 and 3 had similar (p>0.05) lymphocytes (L) values at $50.15 \%$ and $50.10 \%$, respectively. The lymphocytes (L) value of $51.15 \%$ obtained for pigs on diet 4 was also significantly different $(\mathrm{p}<0.05)$ from the other lymphocytes $(\mathrm{L})$ values.

Apart from the significantly lowest monocytes (M) value of $8.10 \%$ obtained for pigs on diet 1 , other monocytes values were similar ( $p>0.05$ ) at $0.15 \%, 10.05 \%$ and $10.15 \%$ for pigs on diets 2,3 and 4 , respectively.

Apart from pigs on diet 3 which had a significantly highest $(p<0.05)$ eosinophils $(E)$ value of $5.05 \%$, other values were similar ( $p>0.05$ ) at $4.05 \%, 4.10 \%$ and $4.05 \%$ for pigs on diets 1,2 and 4 , respectively.

Packed cell volume (PCV) for TDLM inclusion diets were superior to the control diet (0\% TDLM). This report was similar to that where broiler chicks were served fluted pumpkin (Telfaria Occidentalis) leaves extract supplement [23]. It could also be related to the ability of Tithonia diversifolia leaf meal to provide and maintain the essential amino acids and minerals in the diets which are necessary for the normal functioning of the blood cells producing tissues and organs [9]. The range of PCV in this study (30.20 to 41.06\%) was different and higher than that reported as 29.0 to $38.0 \%$ [24], but lower than the reported value of $41.50 \%$ [23] when broiler chicken were fed fluted pumpkin leaves extract supplement.

The supplementation of the diets at 0,10,20 and 30\% TDLM inclusion levels was followed by a significant increase in packed cell volume (PCV). The phytochemical profile of TDLM revealed high levels of flavonoids and phytin [25]. Moreover, sesquiterpene lactones in TDLM were reported to be free radical scavengers [26]. It is therefore conceivable that these components may have competed with haemoglobin $(\mathrm{Hb})$ in red blood cell (RBC) for oxygen, resulting in hypoxea which stimulated synthesis and RBC production. It is also possible that the end product of TDLM metabolism in the body stimulated the kidney directly to cause formation of and secretion of erythroprotein, and also production of cortisol (stress) which are humoral regulators of RBC production [27, 28].

TDLM produced a significant increase in white blood cell (WBC) of the animals in a dose dependent pattern where WBC value increased as the level of TDLM in diets increased, which was different from that reported that gradual decrease in the value of WBC with increasing levels of TDLM in poultry diets [29], but similar to report where broiler chicks were served fluted pumpkin (Telfaria Occidentalis) leaves extract supplement [23].

The significant increase level of WBC, could be attributed to the presence of sesquiterpene lactones which are feeding deterrents that were found in the leaves of Tithonia diversifolia [15]. It could also be related to the ability of TDLM leaf meal to provide and maintain the essential amino acids and minerals in the diets which are necessary for the normal functioning of the blood cells producing tissues and organs [9]. It has been reported that granulocyte-macrophage colony stimulating factor, interleukins IL-2, IL-4 and IL- 5 regulate the proliferation, differenciation maturation of committed stem cells responsible for the production of white blood cells $[30,31]$. It is suggestive therefore, that Tithonia diversifolia has immunostimulatory effects.

With the exception of the value of lymphocyte (L) which was the highest for pigs placed on the control diet $(0 \%)$, other parameters like PCV, WBC (20\% and 30\%), neutrophils (N), monocytes (M) and eosinophils (E) (10\% and 20\%), for TDLM inclusion diets were superior to the control diet (0\% TDLM).

Increase in WBC differentials (in 20\% and 30\% inclusion) cut across all the cell types including the neutrophils, lymphocytes, monocytes and oesinophils. At 10\% TDLM inclusion level, there was reduction in the WBC value. This suggests that the 20\% and 30\% TDLM inclusion levels could be prescribed for medicinal (immunostimulation) purposes and as such, period of exposure should not be protracted, otherwise toxicosis could set in. The $10 \%$ inclusion had no negative effect on the WBC. 


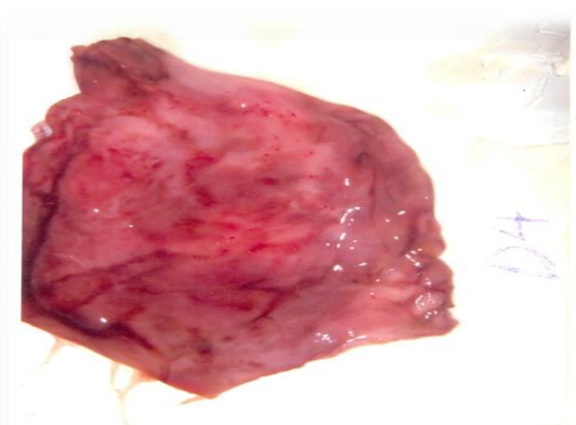

Photo 1: Inflammation and necrosis of the wall of the stomach of pig fed TDLM highest level of $30 \%$.

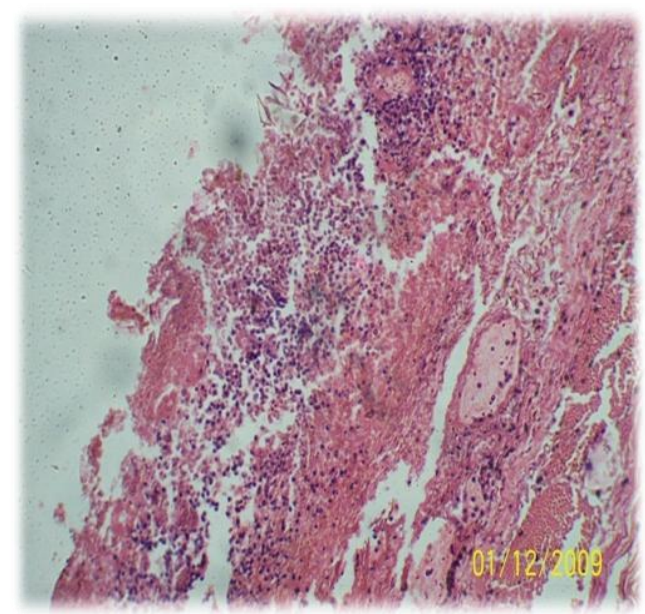

Photo 3: Histopathology of the large intestine of pig fed TDLM at $30 \%$ inclusion level showing severe epithelial erosion and necrosis, with neutrophilic cellular infiltration (Mag. X40). infiltration (Mag. X400).

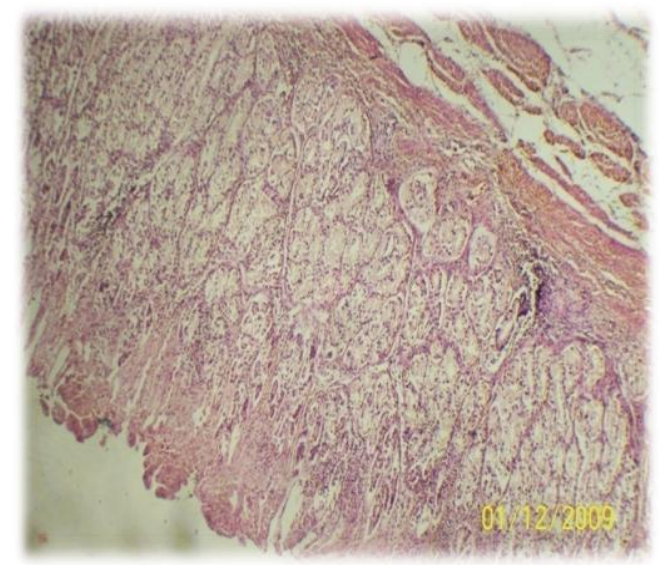

Photo 5: Histopathological appearance of the small intestine of pig fed highest level of TDLM at $30 \%$ inclusion level showing the stunted structure of the villi with no visible lesions on other parts (Mag. X40).

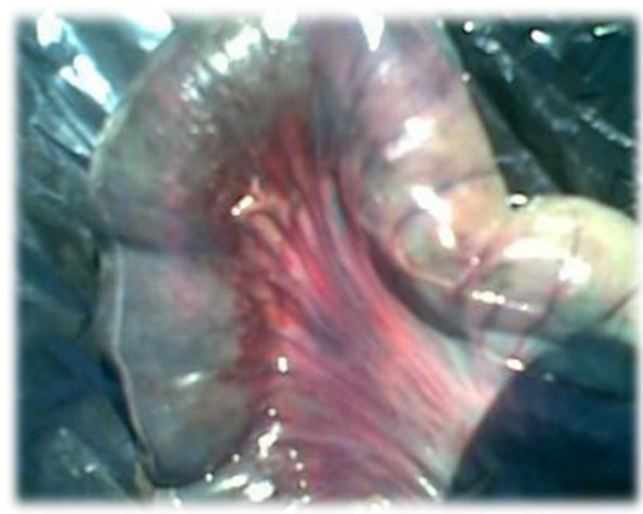

Photo 2: External degeneration and inflammation of large intestine of pig fed highest TDLM dietary inclusion of $30 \%$.

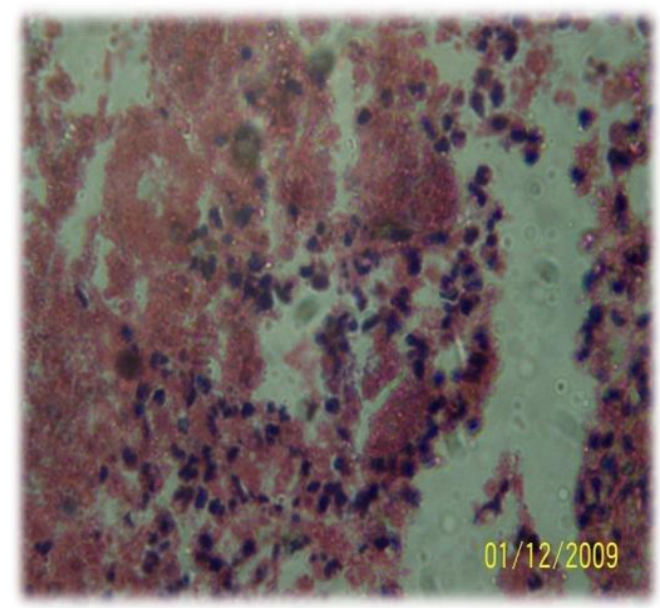

Photo 4: Histopathology of the large intestine of pig fed TDLM at 30\% inclusion level showing severe epithelial necrosis, with neutrophilic cellular

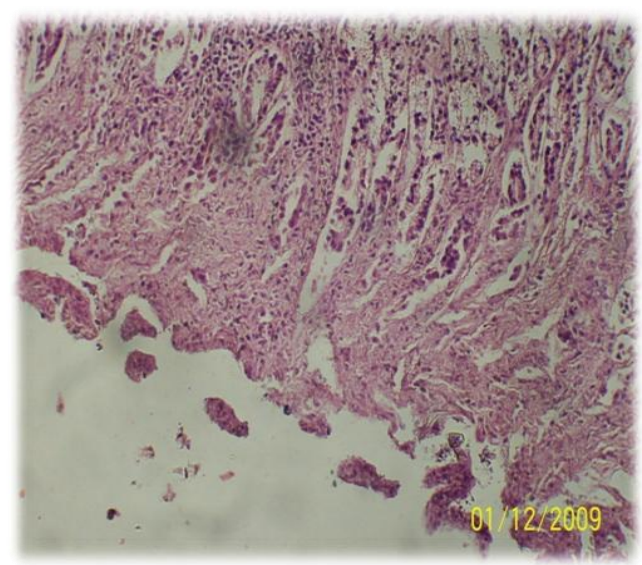

Photo 6: Histopathological appearance of the small intestine of pig fed highest level of TDLM at 30\% inclusion level showing the stunted structure of the villi with no visible lesions on other parts (Mag. X100). 


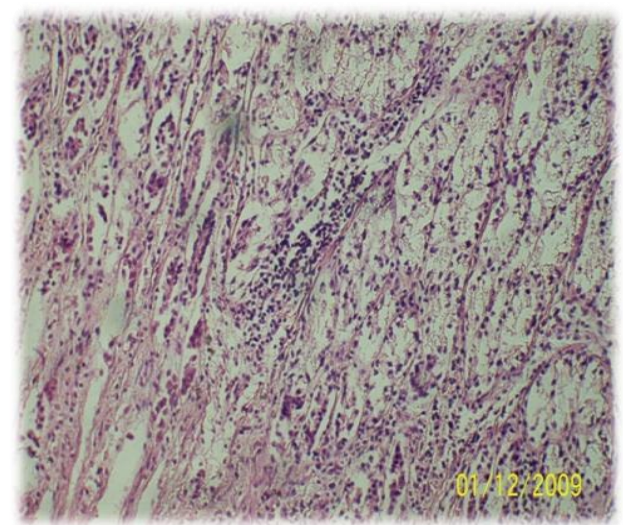

Photo 7: Histopathological appearance of the small intestine of pig fed highest level of TDLM at $30 \%$ inclusion level showing the stunted structure villi with no visible lesions on other parts (Mag. X400).

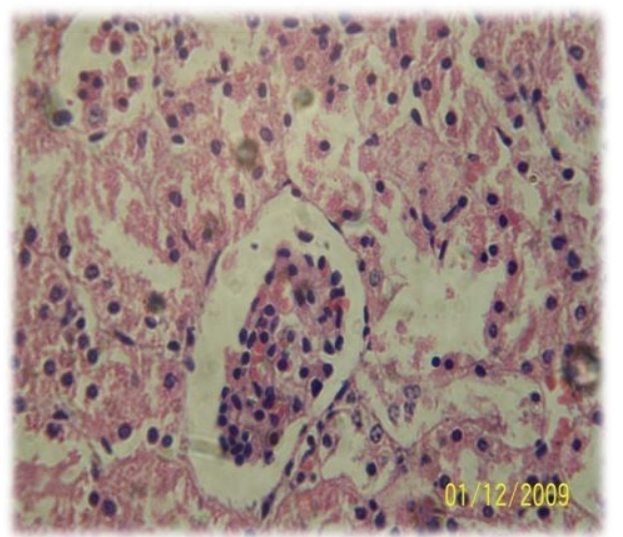

Photo 9: Histopathology of kidney of pig fed TDLM at $30 \%$ inclusion level, showing all the altra structures without any visible leison (Mag. X400).

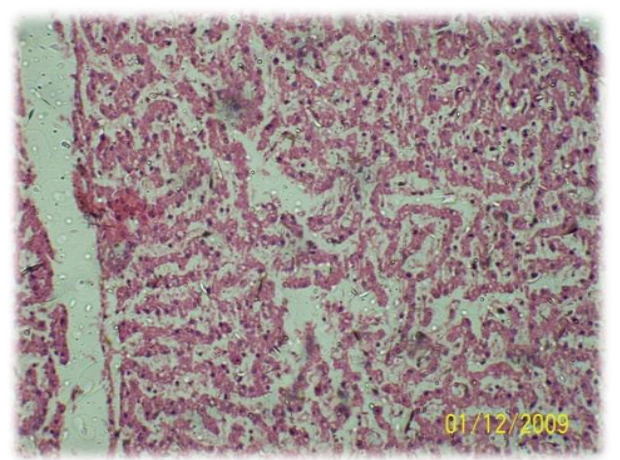

Photo 11: Histopathology of the liver obtained from pigs fed highest level of TDLM at $30 \%$ suggesting hepatic degeneration and necrosis, with the presence of inflamatory cells in the tissues (Mag. X100).

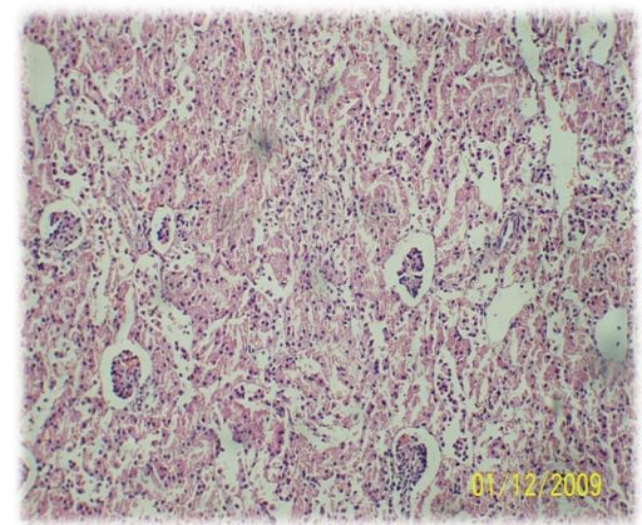

Photo 8: Histopathology of kidney of pig fed TDLM at $30 \%$ inclusion level, showing all the altra structures without any visible leisonof the (Mag. X100).

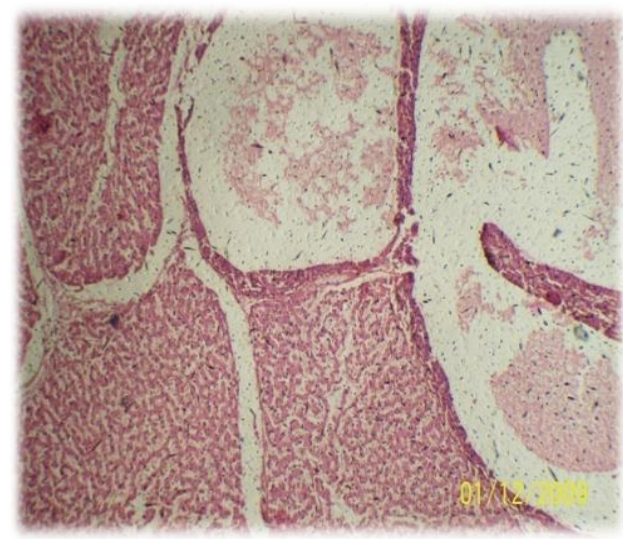

Photo 10: Histopathology of the liver obtained for pigs fed highest level of TDLM at $30 \%$ suggesting hepatic degeneration and necrosis, with the presence of inflamatory cells in the tissues (Mag. X40).

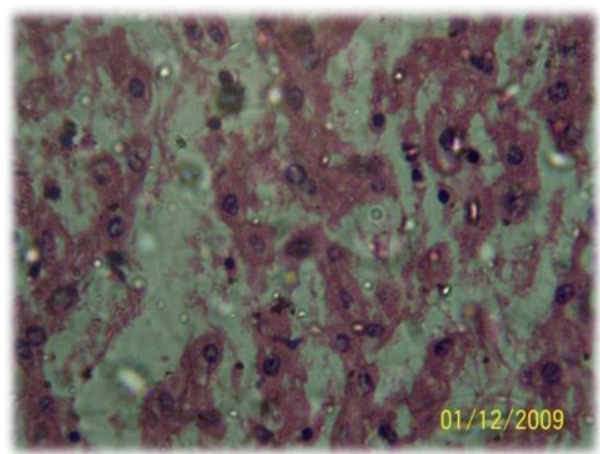

Photo 12: Histopathology of the liver obtained for pigs fed highest level of TDLM at 30\% suggesting hepatic degeneration and necrosis, with the presence of inflamatory cells in the tissues (Mag. X400). 


\subsection{Effect of TDLM as protein supplement on serum metabolites of experimental pigs}

Serum metabolites of experimental pigs fed varying levels of TDLM based diets are presented in Table 2. The values of urea in the blood of pigs on diet 1 (control), 2 (10\% TDLM inclusion), 3 (20\% TDLM inclusion) and $4(30 \%$ TDLM inclusion) at $5.89 \mathrm{mmol} / \mathrm{l}, 3.72 \mathrm{mmol} / \mathrm{l}, 6.04 \mathrm{mmol} / \mathrm{l}$ and $4.19 \mathrm{mmol} / \mathrm{l}$ were significantly different $(\mathrm{p}<0.05)$. Pigs on diet 3 had the highest significant $(\mathrm{p}<0.05)$ urea level, while pigs on diet 2 had the significantly lowest urea level. Creatinine levels of pigs on diets 3 and 4 were similar ( $>0.05)$ at $150.06 \mathrm{umol} / \mathrm{l}$ and $150.12 \mathrm{umol} / \mathrm{l}$ respectively. The highest significantly different $(\mathrm{p}<0.05)$ value of 163.69 umol/1 was obtained for pigs on diet 1 , while pigs on diet 2 had the lowest significantly different $(\mathrm{p}<0.05)$ value of creatinine at $136.39 \mathrm{umol} / \mathrm{l}$. There were significant differences $(\mathrm{p}<0.05)$ in the total cholesterol contents in the blood samples of pigs on diets 4, 3, 1 and 2 in a decreasing order of $5.94 \mathrm{umol} / \mathrm{l}, 4.90 \mathrm{umol} / \mathrm{l}, 4.42 \mathrm{umol} / \mathrm{l}$ and $4.15 \mathrm{umol} / \mathrm{l}$, respectively. Serum triglyceride content of $1.06 \mathrm{mmol} / \mathrm{l}$ obtained for pigs on the control diet 1 was the highest and significantly different $(\mathrm{p}<0.05)$ from other values. The triglyceride contents of pigs on diets 3 and 4 had similar $(p<0.05)$ values of $0.36 \mathrm{mmol} / \mathrm{l}$ and $0.37 \mathrm{mmol} / \mathrm{l}$, respectively. There seemed to be a decreasing trend in the triglyceride contents from diet 1 to diet 3.

There were significant differences $(\mathrm{p}<0.05)$ in the values of aspartate aminotransferase (AST) obtained for all experimental pigs on diets 1, 2, 3 and 4. Experimental pigs on diet 2 had the highest value of 125. 10 $\mathrm{mmol} / \mathrm{l}$, while pigs on diet 4 had the lowest value of $49.15 \mathrm{mmol} / \mathrm{l}$. Alanine aminotransferase (ALT) value obtained for pigs on diet 3 (20\% TDLM inclusion) was significantly different $(\mathrm{p}<0.05)$ and was the highest at $39.05 \mathrm{mmol} / \mathrm{l}$, while pigs on diet $4(30 \%$ TDLM inclusion) had the significantly lowest $(\mathrm{p}<0.05)$ value of 25.15 $\mathrm{mmol} / \mathrm{l}$. Pigs on control diet 1 had the significantly highest $(\mathrm{p}<0.05)$ gamma-glutamyltransferase $(\mathrm{GGT})$ level of $42.44 \mathrm{mmol} / \mathrm{l}$, followed by $31.86 \mathrm{mmol} / \mathrm{l}$ obtained for pigs on diet 3 . Pigs on diets 2 and 4 had similar ( $>0.05$ ) gamma-glutamyltransferase (GGT) values of $10.56 \mathrm{mmol} / \mathrm{l}$ and $10.65 \mathrm{mmol} / \mathrm{l}$, respectively.

Pigs on diet 1 had the highest alkaline phosphatase (ALP) value of $107.70 \mathrm{mmol} / \mathrm{l}$ and pigs on diet 3 had the lowest alkaline phosphatase value (ALP) of $73.10 \mathrm{mmol} / 1$. There was no significant differences $(\mathrm{p}>0.05)$ among total protein (TP) mean values obtained for all experimental pigs on varying TDLM dietary treatments.

The TP values of $0.46 \mathrm{ng} / \mathrm{l}, 0.47 \mathrm{ng} / \mathrm{l}, 0.45 \mathrm{ng} / \mathrm{l}$ and $0.48 \mathrm{ng} / \mathrm{l}$ obtained for pigs on diets $1,2,3$ and 4 were similar $(\mathrm{p}>0.05)$.

There were significant differences $(\mathrm{p}<0.05)$ in the values of albumin contents in the blood samples of pigs on experimental diets. The values of those on diet 4 was signifcantly superior $(\mathrm{p}<0.05)$ to other diets at $29.10 \mathrm{ng} / \mathrm{l}$. This value was closely followed by those on diet 2,1 and 3 at $28.18 \mathrm{ng} / \mathrm{l}, 26.28 \mathrm{ng} / \mathrm{l}$ and $24.42 \mathrm{ng} / \mathrm{l}$, respectively.

Of all the serum metabolite parameters examined, only the total protein was not affected significantly by the inclusion levels of TDLM for all the experimental diets, including the control. This further ascertained the fact that TDLM is fortified with protein and all other esssential amino acids [32]. However, this report differs from the one where significant difference occurred in the total protein value of birds served fluted pumpkin leaves extract supplement [23], but similar to study where total protein did not vary significantly in all diets when birds were served Telfairia occidentalis leaf meal as protein supplement [5].

Total protein is an indirect index for measuring the nutritional protein adequacy [33, 34]. Similarity between the control and the other diets with TDLM inclusions observed in this study suggests that the nutritional quality of TDLM as a protein source may be acceptable, as it compared favourably with other known conventional sources $[35,36]$.

The values of urea, triglyceride, alanine aminotransferase (ALT) and gamma-glutamyl transferase (YGT) which were significantly different for all the experimental diets, also followed a pattern of initial increase and gradual decrease as the level of inclusion of TDLM increased. This increase took place mostly at $20 \%$ TDLM inclusion level.

Values of urea were higher on pigs served TDLM compared to the control diets. The value of urea which ranged from 3.72 to $6.04 \mathrm{mmol} / \mathrm{l}$ in this study is considerably lower than 21.01 to $24.00 \mathrm{mmol} / \mathrm{l}$ when broilers were served mimosa leaf meal [37] and 10.01 to $19.00 \mathrm{mmol} / \mathrm{l}$ when broilers were served fluted pumpkin leaves extract [23]. Previous reports [34, 38] emphasised that urea depends on both the quality and quantity of the protein supplied in the diet of pigs. Higher levels of urea in blood could be attributed to the presence of some anti-nutritional factors which might have lowered the quality of the protein, indicating imbalance of amino acids in the diet, which caused elevated blood urea concentration.

The urea and creatinine values which reduced across the increasing inclusion with little consistency indicates that Tithonia diversifolia has no nephotoxic bioactive principles.

Increase in urea and creatinine values are cardinal in diagnosis of kidney toxicosis and kidney malformation may raise the level of blood urea [39]. This is supported by the histopathological pictures (Photos 8 and 9) of the kidney of pig fed highest TDLM level of 30\%, revealing all the ultrastructures without any visible lesion. 
Fatalities in the high TDLM inclusions could be majorly attributed to the degeneration, bleeding and inflammation of the stomach inner linnings and external appearance of the large intestine (Photos 1 and 2).

Moreover, severe epithelia erosion and necrosis, with neutrophilic cellular infiltration (Photo 3 and 4) were observed in the histopathological appearance of the large intestine, and stunted structure of the villi of the small intestine with no visible lesions on other parts (Photos 5, 6 and 7). This was evidently captured by the pictorial images of the large intestine with clear haemorrages and congested mesentries (Photo 2).

At the highest TDLM inclusion of 30\%, a collaborative and additive irritating effects of the bioactive components such as tagitinins $\mathrm{A}, \mathrm{B}, \mathrm{C}$ and $\mathrm{F}$ with diversifol, tirotundin, tithonine and sulphurein were suspects [40].

The liver enzymes such as alanine amminotransferase (ALT) and aspartate amminotransferase (AST) had reduced values at 30\% inclusion of TDLM. Value of ALT was higher on pigs served 20\% TDLM compared to the control diet and ALT value in this study, at 25.15 to $34.5 \mathrm{mmol} / 1$ was higher than previous report at 23.50 to $24.84 \mathrm{mmol} / 1$ [23]. This shows that TDLM is not hepatotoxic though histopathological pictures (Photos 10, 11 and 12) of the liver obtained for pigs fed highest level of 30\% TDLM suggest hepatic degeneration and necrosis, with the presence of inflamatory cells in the tissues. These effects may be associated with haematological effects of increased WBC infilteration at highest inclusion level of TDLM at 30\%.

Alkaline phosphate (ALP) value was observed to decrease at 20\% TDLM inclusion, but later increased at 30\% TDLM inclusion. Previous report [41] stated that ALP activity can be utilized to assess the health of the liver as it owes its origin to the osteoblasts and some of it are normally excreted in the bile. So, if there is interference of bile flow, the ALP activity is said to be increased. In some abnormal cases when there is biliary stasis, excessive ALP may be formed by the liver.

Albumin value was observed to decrease at 20\% TDLM inclusion, but later increased at 30\% TDLM inclusion.The significant albumin variation for all diets in this study contradicted the report when Telfaira occidentalis leaf meal was served as protein supplement to broilers [5], but similar to the significant difference reported when fluted pumpkin leaves extract supplement was served to broilers [23]. Previous reports stated that the most sensitive biochemical indices of mild or impending protein deficiency is a drop in serum albumin into the marginal range $[42,43]$.

It has been reported that a reading of total albumin than the normal physiological value usually indicates hypo-albuminemia which may result from deficient intake of protein, deficient synthesis of albumin, excess protein breakdown, chronic liver diseases, starvation and chronic gastro-intestinal disease with their interference with protein digestion and absorption [4]. However, hyper-albuminemia are rarely seen except in cases of dehydration and shock. Generally speaking, increase in albumin are masked by increase in total plasma volume [45].

Total cholesterol in the control diet was higher than the 10\% TDLM inclusion, but gradual increase was observed as the inclusion level of TDLM increased from $20 \%$ to $30 \%$. Values of cholesterol ranged from 4.15 to $5.94 \mathrm{mmol} / \mathrm{l}$ which was different from other reported values at 143.10 to $163.00 \mathrm{mmol} / \mathrm{l}$ [23].

Cholesterol is an essential structural component of cell membrane and lipo proteins and serve as the prosecutor for steroid hormones and bile acids [46]. There is an association between blood levels of cholesterol and the risk of coronary heart disease in humans [47] and premature development of atherosclerosis [48].

The high cholesterol recorded for diet 4 (30\% TDLM inclusion) could be attributed to the presence of high saponin content which has been shown to bind to serum lipids, especially cholesterol, thereby, easing their excretion from circulation [49]. It has further been enlightened that increased blood cholesterol values are found in the following conditions: chronic and acute nephritis, chronic nephosis, diabetes mellitus, high liquid hypothyroidism and biliary obstruction [41]. These conditions were lacking in this present.

Anti-lipidemic properties have been well defined [50] and the increased cholesterol and reduced triglyceride across the increasing inclusion levels of TDLM underscores TDLM as an anti-lipidemic agent. This suggests that TDLM could be used to treat some metabolic conditions involving fatty acids and glucose in animals.

\section{Conclusions}

All haematological parameters and serum metabolites examined indicated safe nutritional regimes up to $20 \%$ TDLM inclusion. The abnormal excessive activity of ALP in the liver seemed reduced or normalised at $20 \%$ TDLM inclusion in pigs' diets.

Tithonia diversifolia leaf meal (TDLM) could be a suitable health diet to combact some fatty acid metabolic diseases at $10 \%$ inclusion in the diet of pigs. The histopathology revealing severe epithelial erosion and haemorrages could be instructive of the toxicological effects of TDLM at high inclusion levels above $20 \%$. 


\section{References}

[1]. G.M. Babatunde, A.O. Fajimi, and A.O. Oyejide, Rubber seed oil versus palm oil in broiler chicken diets. Effects on performance, nutrient digestibility, haematology and carcass characteristics, Animal Feed Science Technology, 35, 1992, $133-146$.

[2]. R.K. Murray, P.A. Grannes, P.A. Mayer, and V.W. Rodwell, Harper's biochemistry. 20th edition. (Mcgraw-Hill, 2000). 594-602

[3]. J.E. Okonkwo, K.C. Iyadi, and C.O. Effiong, 2004. Effect of chronic administration of haematological parameters of rats. Nigeria Journal of Physiology Science, 19, 2004, 10-13.

[4]. M.T. Yakubu, M.A. Akanji, and A.T. Oladiji, Haematological evaluation in male albino rats following chronic administration of aqueous extract of Fadogia agretis stem, Pharmacognosis Magazine, 3(1),2007, 34-38.

[5]. A.O. Fasuyi, and A.D. Nonyerem, Biochemical, nutritional and haematological implications of Telfaira occidentalis leaf meal as protein supplement in broiler starter diets, African Journal of Biotechnology, 6(8),2007, 1055-1063.

[6]. V.C. Speer, Partitioning nitrogen and amino acid for pregnancy and lactation in swine, A Review Journal of Animal science, $68,1990,553-561$.

[7]. G.O. Farinu, Chemical composition of some plant products of the savannah forest zone of Nigeria, Food Chemistry 22, 1986, 315320.

[8]. P.P. Dutta, P. R. Bharatacharyya, I.C. Rabha, O.N. Bordolon, N.C. Barna, P.K. Chowdurry, P.R. Sharma, and J.N. Barna, Feeding deterrents for philosamiaricini (Samia cynthia, Subrp. Ricins) from Tithonia diversifolia, Phytoparasitica, 14, 1986, 77-80.

[9]. T.B. Olayeni, G.O. Farinu, V.A. Togun, O.S. Adedeji, and A.O. Aderinola, Performance and Haematological Characteristics of Weaner Pigs Fed Wild Sunflower (Tithonia diversifolia Hemsl A Grey) Leaf Meal, Journal of Animal and Veterinary Advances, $5(6), 2006,499-502$.

[10]. A.A. Odunsi, G.O. Farinu, and J.O. Akinola, Influence of dietary wild sunflower (Tithonia diversifolia Hemsl.A.Gray) leaf meal on layers performance and egg quality, Nigerian Journal of Animal Production, 23, 1996, 28-32.

[11]. G.O. Farinu, A.A. Odunsi, J.O. Akinola, and V.A. Togun, Yield and chemical composition of wild sunflower (Tithonia diversifolia) Hemls A. Gray and feeding value of wild sunflower forage meal in broiler chicken diets, Tropical Journal of Animal Science, 2 , 1999, 31-37.

[12]. B. Norachack, S. Keonouchanh, C. Ty, B. Bouahom, and T.R. Preston, Stylosanthes and cassava leaves protein supplements to a basal diet of broken rice for local pigs, Livestock Research for Rural Development 16(10). http://www.cipav.org.co/lrrd/lrrd16/10/boun16074.htm

[13]. J.V. Dacie, and S.M. Lewis, Practical haematology (Churchhill Livington, England, 7th Edn. 1991).

[14]. C.N. Jain, Schalm's veterinary haematology ( Lea and Febiger, Philadelhia, 4th Edn. 1986).

[15]. B.M. Mitruka, and H. Rawnsley, In: clinical, biochemical and haematological reference values in normal experimental animals (Masson Publication U.S.A. Inc. New York, 1977).

[16]. A. Kaplan, and I.I. Szabo, Clinical chemistry: interpretation and technique. (Henry Kumpton Publishers, London, 1st Edn.).

[17]. P. Roschlan, E. Bernet, and W. Guber, 1974. Enzymatische bestimmung des gesant cholesterium in serum. Journal of Clinical Biochemistry, 12, 1974, $403-407$.

[18]. R. Rej, and M. Holder, Aspartate aminotransferase. In: Methods of enzymatic analysis (Bergmeyer, H.U., J. Bergmeyer and M. Gassl (Eds.) Weinhein Velag Chemie, 1983).

[19]. M. Holder, and R. Rej, Alanine aminotransferase. In: Methods of enzymatics analysis (Bergmeyer, H.U., J. Bergmeyers and M. Gassl (Eds.) Weinhein Velag Chemie, 1983).

[20]. T. Peters, G.T. Biamonte, and B.T. Doumas, Protein (total protein) in serum. In: selected methods of clinical chemistry, American Association of Clinical Chemistry, 1982, $100-115$.

[21]. M.E. Jules, Principles and techniques in diagnostic histopathology: developments in immunohistochemistry and enzyme histochemistry (Nayes Publications, University of Michigan, 1982).

[22]. Minitab, Computer Software Package, One-way analysis of variance (ANOVA), (Minitab incorporated, 2005 http://www.minitab.com).

[23]. F.C. Nworgu, S.A. Ogungbenro, and K. S. Solesi, Performance and some blood chemistry indices of broiler chicken served fluted pumpkin (Telfaria occidentalis) leaves extract supplement, American Eurasian Journal of Agricultural \& Environmental Science, 2(1), 2007, 90-98.

[24]. F.C Iheukwumere, and H. Herbert, Physiological of broiler chickens to quantitative water restrictions: haematology and serum biochemistry, International Journal of poultry Science 2, 2003, 117-119.

[25]. A.O. Fasuyi, F.A.S. Dairo, and F.J. Ibitayo, Ensiling wild sunflower (Tithonia diversifolia) leaves with sugar cane molasses. Livestock Research for Rural Development 22 (3), 2010, www.lrrd.org/lrrd22/fasu22042.htm

[26]. J.Q. Gu, J.J. Gills, E.J. Park, E. Mata-Greenwood, M.E. Hawthomeb, F. Axelin, P.L. Charez, H.H. Fong, R.G. Methta, J.M. Pezzuto, and J. Kinghor, Sesquiterpenes from Tithonia diversifolia with potential cancer chemo-preventive activity, Journal of National Production 65, 2002, 532 - 536.

[27]. T. Sanchez-Elsner, J. R. Ramirez, F. Rodrigues-Sanz, E. Varela, C. Bernabew, and L.M. Botella, A cross talk between hypoxia and TGF-beta orchestrates gene regulation through Spi and Smads, Journal of Molecular Biology. 36(1), 2004, 9-24.

[28]. Alo, O.S., M.O. Oyebanji and M.O. Abatan, Haematological and immunological effect on chicken exposed to aflatoxin, Veterinary World Journal 2(1), 2009, 5-7.

[29]. G.O. Farinu, Agronomic and nutritive evaluation of the wild sunflower (Tithonia diversifolia Hemsl. A.Gray), Comprehensive Project Implementation Brief 1996, 1-6.

[30]. A.C. Guyton, and J.E. Hall, A Textbook on Medical Physiology. 10th Edition (Saunder Company, Philadelphia, 2000).

[31]. W.F. Ganong, Large Medical Books (McGraw Hill Companies Inc. 20th Edition New York, 2001).

[32]. S.O.C. Ugwu, and C.O. Chukwuka, 2001. The effects of inclusion of dried centre (Centrocema pubescens) leaves as a source of protein in the diet of growing pigs, Proc. 6th Annual Conference of Animal Science Association of Nigeria held at the University of Maiduguri, Maiduguri, 2001, 81-82.

[33]. O.O. Tewe, Cyanogenic glucoside, protein interaction in cassava peel based rations: effect on some haematological parameters in growing pigs. Nutrition Report International, 30, 1985, 425-431.

[34]. B.O. Eggum, Protein quality of cassava leaf. British, Journal of Nutrient, 24, 1970, 761-768.

[35]. C.I.R. Katto, and A. Salazar, Boton de oro (Tithonia diversifolia (Hemsl) Gray) una fuente proteica alternativo para el tropic, Livestock Research for Rural Development 6(3), 1995.

[36]. L. Mahecha, and M. Rosales, Nutritional value of the foliage of Wild sunflower (Boton de Oro; (Tithonia diversifolia [hemsl]. Grey) for tropical animal production. Livestock research for rural Development 17(9), 2005, http://www.cipav.org.co/lrrd17/9/mahel7100.htm 
[37]. F.C. Nworgu, Utilization of forage meal supplements in broiler production. Animal Science Department, University of Ibadan, Ibadan, Nigeria, $\mathrm{PhD}, 2004$.

[38]. E.A. Iyayi, and O.O. Tewe, Serum total protein, urea and creatinine levels as indices of quality of cassava diet for pigs. Tropical Veterinary 36, 1998, 59-67.

[39]. J.J. Kaneko, Clinical Biochemistry of Domestic Animals (Academic Press Limited, London, 1989).

[40]. N.C. Baruah, J.C. Sarma, N.C. Barua, S. Sarma, and R.P. Sharma, Germination and growth inhibitory sesquiterpene lactones and a flavour from Tithonia diversifolia, Phytochemistry 36, 1994, $29-36$.

[41]. A.S. Ganti, Veterinary Clinical pathology (College of Veterinary Science, Tirupati, 1979).

[42]. J.F. Brock, Recent advances in human nutrition (Little Brown Publishers, Boston, Massachussets. U.S.A., 1961).

[43]. J.G. Ross, G. Christie, W.G. Halliday, and R.M. Jones, Haematological and Blood Chemistry comparison values for clinical pathology in poultry. Veterinary Record 102, 1978, 29-30.

[44]. R.B. Altman, Avian Clinical Pathology, radiology, parasitic and infectious disease, Proc. American Animal Hospital Association, South Bend, W, 1979.

[45]. Cole, E.H., Veterinary Clinical Pathology (Sauders Co., Philadephia, London and Toronto, 1986).

[46]. P.L. Yeagle, Biology of cholesterol (CRS Press. Boca Ration, Florida, USA, 1988).

[47]. T. Stamler, D. Wentworth, and J.D. Neaton, Is relationship between serum cholesterol and risk of premature death from coronary heart disease continuous and graded? Journal of American Medical Association, 256, 1986, 2823-2828.

[48]. M.F. Oliver, 1990. Lipid and coronary disease - Resolved and unresolved problems, British Medical Bulletin 46, 1990 , 865-872.

[49]. A.G. Matawalli, A.C. Samuel, and S. Yagana, 2004. Effects of methanolic leaf extract of Adunsonia digitata on serum lipid levels in normal and ethanol fed rate, Pakistan Journal of Biological Science, 7, 2004, 1094-1095.

[50]. J.O. Adebayo, E.A. Balogun, and S.A. Oyeleke, 2009. Toxicity study of the aqueous extract of Tithonia diversifolia leaves using selected biochemical parameters in rats, Pharmacognosis Research 1(3), 2009, 143 - 147. 